\title{
PENGEMBANGAN VIRTUAL REALITY UNTUK DIGITALISASI PURA PENATARAN AGUNG DI PURA BESAKIH
}

\author{
I Wayan Andika Raditya1, I Gede Mahendra Darmawiguna2, I Gede Partha Sindu3
}

1,3 Prodi Pendidikan Teknik Informatika, 2Prodi Sistem Informasi, Jurusan Teknik Informatika, Fakultas Teknik dan Kejuruan Universitas Pendidikan Ganesha, Jln. Udayana No. 11 Singaraja 81116 INDONESIA

\begin{abstract}
Abstrak
Pengembangan Virtual Reality untuk Digitalisasi Pura Penataran Agung bagian Mandala 1, 5, 6 dan 7 merupakan salah satu pemanfaatan teknologi yang digunakan sebagai media konservasi untuk melestarikan Pura Penataran Agung bagian Mandala 1, 5, 6 dan 7 sebagai bagian dari Pura Agung Besakih dan juga sebagai warisan budaya. Media berupa aplikasi Virtual Reality ini mengajak pengguna untuk dapat melihat keadaan Pura Penataran Agung Besakih bagian Mandala 1, 5, 6 dan 7 dengan detail selain itu pengguna juga dapat melakukan perpindahan ke arah mana yang ingin dilihat sehingga dirasakan sebuah pengalaman seolah-olah berada di Pura Penataran Agung Besakih bagian Mandala 1, 5, 6 dan 7. Pengembangan Virtual Reality untuk Digitalisasi Pura Penataran Agung Besakih bagian Mandala 1, 5, 6 dan 7 menggunakan metode waterfall. Pengujian penelitian ini menggunakan 6 tahapan proses pengujian : (1) Uji whitebox dengan penerapan di setiap prosesnya sudah sesuai, (2) uji blackbox dengan 5 responden didapat hasil tidak terdapat kesalahan, (3) uji usability dengan 5 responden di dapat rata-rata persentase $80 \%$ termasuk baik, (4) uji performance efficiency dengan 5 responden didapatkan rata-rata persentase $86 \%$ termasuk sangat baik, (5) uji data integrity dengan 2 responden ahli di dapat rata-rata persentase $89 \%$ termasuk sangat baik(6) uji User Experience Questionnaire (UEQ) di dapat persentase rata-rata dari 20 responden dengan hasil positif.
\end{abstract}

Kata Kunci:

Virtual Reality, Digitalisasi 3D, Warisan Budaya Bali, Pura Besakih

\begin{abstract}
Development of Virtual Reality for Digitization of the Penataran Agung Temple Mandala parts 1, 5, 6 and 7 is one of the uses of technology that is used as a conservation medium to preserve the Penataran Agung Temple Mandala parts 1, 5, 6 and 7 as part of the Besakih Agung Temple and also as cultural heritage. The media in the form of Virtual Reality application invites users to be able to see the state of the Penataran Agung Besakih Temple Mandala parts 1, 5, 6 and 7 in detail, besides that the user can also move to which direction he wants to be seen so that an experience is felt as if in Penataran Agung Besakih Temple Mandala parts 1, 5, 6 and 7. Development of Virtual Reality for Digitizing Penataran Agung Temple Besakih Mandala parts 1, 5, 6 and 7 using the waterfall method. The testing of this study uses 6 stages of the testing process: (1) The whitebox test with the application in each process is appropriate, (2) the blackbox test with 5 respondents found that there are no errors, (3) usability test with 5 respondents obtained the average percentage $80 \%$ including good, (4) performance efficiency test with 5 respondents found an average percentage of $86 \%$ including very good, (5) data integrity test with 2 expert respondents at an average percentage of $89 \%$ including very good (6) test User Experience Questionnaire (UEQ) obtained an average percentage of 20 respondents with positive results..
\end{abstract}

Keywords:

Virtual Reality, 3D

Digitalization, Balinese Cultural Heritages, Besakih Temple

\footnotetext{
*Korespondensi

E-mail: bitboxk@gmail.com, mahendra.darmawiguna@undiksha.ac.id, partha.sindu@undiksha.ac.id
} 


\section{PENDAHULUAN}

Bali merupakan salah satu provinsi di Indonesia dan juga salah satu pulau di Kepulauan Nusa Tenggara. Keberagaman seni dan budaya Bali merupakan salah satu daya tarik wisatawan domestik maupun internasional untuk menikmati keaslian dan kekhasan dari adanya kebudayaan Bali. Oleh karena itu kebudayaan Bali sebagai kebudayaan daerah yang akan mewujudkan kebudayaan nusantara sebagai warisan budaya.

Warisan budaya pada Pasal 1 Konvensi dari The World Heritage Convention membagi menjadi 3 kriteria warisan budaya secara fisik yaitu monumen, kelompok bangunan, dan situs (Pedersen, 2002). Warisan budaya fisik yang berupa peninggalan benda maupun bangunan bersejarah dapat dijadikan ilmu pengetahuan karena memiliki nilai-nilai penting dalam mengetahui perkembangan sejarah. Sehingga perlu adanya pengelolaan warisan budaya dengan melakukan pelestarian atau konservasi.

Konservasi merupakan segenap proses pengelolaan suatu tempat agar makna kultural yang dikandungnya terpelihara dengan baik. Dengan kata lain untuk mempertahankan warisan budaya dalam jangka waktu panjang sehingga nilai-nilai yang terkandung dapat diturunkan ke generasi berikutnya. Terutama warisan budaya fisik di Pulau Bali sangat perlu dilestarikan, salah satunya situs pura yang juga merupakan ikon Pulau Bali.

Adapun empat macam situs pura yang menata kehidupan sosial di Bali yaitu Pura Kawitan, Pura Swagina, Pura Kahyangan Desa, dan Pura Kahyangan Jagat. Pura Kahyangan Jagat merupakan tempat pemujaan umat Hindu yang bersifat universal dimana seluruh umat ciptaan Tuhan sejagat diperbolehkan untuk bersembahyang disana. Salah satu pura di Bali yang termasuk Pura Kahyangan Jagat yaitu Pura Besakih. Pura Besakih merupakan salah satu pura utama dan sekaligus pura terbesar di Bali dengan ada 18 pura utama yang berada di dalam Pura Besakih (Sutriyanti, 2015). Pura Besakih dalam kedudukannya sebagai Pura Kahyangan Jagat memiliki fungsi atau konsep yaitu Pura Kahyangan Rwa Bhineda, dimana Pura Besakih disimbolkan sebagai Pura Purusa. Berdasarkan hasil wawancara dari beberapa narasumber, Pura Besakih merupakan pura utama yang sangat berperan penting dalam menata kehidupan sosial masyarakat Bali. Oleh karena itu, Manajemen Pengelola Pura Besakih melarang wisatawan, guide, beserta pedagang untuk memasuki areal Pura di komplek Pura Besakih yang tidak melakukan persembahyangan. Selain itu Pura Besakih berada pada Kawasan yang rawan bencana alam terutama gunung berapi karena letak Pura besakih berada di areal Gunung Agung. Oleh karena itu penting untuk melakukan dokumentasi warisan budaya Bali, selain untuk dapat digunakan dalam memperkenalkan warisan budaya Bali, juga untuk melestarikan warisan budaya. Konsep yang digunakan dalam dokumentasi warisan budaya adalah konsep digitalisasi. Konsep digitalisasi yaitu dengan mengalihkan dari bentuk yang susah diformalisasi dan dikomunisasikan menjadi bentuk yang lebih dipahami dengan bantuan teknologi.

Penelitian terkait Pura Besakih yang dikembangkan oleh Padma Nyoman Crisnapati (2019) dengan judul "3D Digitalization of Besakih Architectural Heritage : Documentation and Preservation". Dalam penelitian ini, tampilan foto digital dikumpulkan sejumlah 458 foto dan digunakan sebagai referensi model 3D untuk Pura Besakih. Pada fase pertama, 9 cetak biru peta didasarkan pada level di Pura Penataran Agung Besakih berhasil dibuat. Di tahap implementasi, pengumpulan hasil foto dari tampilan depan, samping dan belakang didapatkan 49 objek dan dikelompokkan sesuai dengan nama dari objek tersebut untuk dijadikan dalam bentuk 3 Dimensi yang menyerupai dengna ukuran, bentuk dan tekstur asli (Crisnapati, Darmawiguna, Kesiman, \& Wijaya, 2019).

Penelitian terkait Virtual Reality yang dikembangkan oleh Pius Dian Dwi Anggoro (2018) dengan judul "Kajian Interaksi Pengguna Untuk Navigasi Aplikasi Prambanan VR Berbasis Virtual Reality", menampilkan Candi Prambanan beserta lingkungan sekitarnya dalam bentuk 3 dimensi di dalam dunia virtual dengan bantuan alat berupa headset khusus dimana pengguna akan merasa seperti berada di lokasi Candi (Anggoro, 2018).

Penelitian terkait Augmented Reality yang dikembangkan oleh I Gede Mahendra Darmawiguna, et al, (2014) dengan judul "Augmented Reality for the Documentation of Cultural Heritage Building Modelling in Bali, Indonesia", menampilkan objek warisan budaya Pura Besakih, Pura Ulundanu Batur dan Rumah Tradisional di Bali dalam bentuk 3 dimensi yang dikombinasikan dengan buku khusus dengan marker Quick Response Code (QRC) dan ditampilkan lewat kamera smartphone disesuaikan dengan marker di buku ARBook (Darmawiguna, I G M, et al, 2014)

Virtual Reality (VR) merupakan sebuah teknologi yang digunakan untuk membuat lingkungan virtual dimana dapat membuat penggunanya mengalami dan berinteraksi seolah-olah seperti di dunia nyata (M. Nguyen \& H. Le, 2015). Kelebihan utama dari Virtual Reality adalah dapat membuat dan merasakan sensasi dunia nyata secara maya sehingga pengguna menjelajahi dunia tersebut. Sehingga dapat meningkatkan rasa eksistensi yang kuat dalam dunia virtual 3 dimensi bagi pengguna yang jauh serta mampu meningkatkan komunikasi manusia dengan lingkungan sekitar. Dimana pengalaman Virtual Reality yang sempurna dapat mempengaruhi semua indera kita dan memungkinkan kita untuk berinteraksi dengan lingkungan virtual 
lebih nyata seperti yang kita lakukan di lingkungan nyata. Model Virtual Reality yang terintegrasi dengan dokumentasi yan tepat akan jadi alat yang berguna bagi dunia pendidikan maupun khalayak umum, serta dukungan untuk pelestarian dan konservasi warisan budaya.

Untuk memunculkan sensasi nyata dari Virtual Reality diperlukan perangkat pendukung. Perangkat yang digunakan untuk mendukung teknologi Virtual Reality biasanya berupa helm, walker, headset, suit, dan sarung tangan. Perangkat-perangkat tersebut bertujuan untuk melibatkan sebanyak mungkin indera yang dimiliki manusia [12]. Salah satu developer yang mengembangkan perangkat Virtual Reality adalah HTC VIVE. HTC VIVE merupakan alat yang digunakan untuk menunjang teknologi Virtual Reality yang dibuat oleh HTC dan Valve Corporation, perusahaan pengembang game . Di dalam headset ini, lingkungan virtual yang ditampilkan tidak terbatas, dimana batasnya hanya dari kreatifitas dari pembuat game.

Dalam penelitian di Pura Besakih terkait konservasi warisan budaya berbasis digitalisasi, dilakukan pada salah satu pura utama yaitu Pura Penataran Agung. Pura Penataran Agung adalah komplek Pura Besakih yang paling sentral dan paling utama di Besakih dan juga yang terbesar dari 18 kelompok pura di Besakih, itu terlihat dari keseluruhan jumlah pelinggih di Pura Penataran Agung Besakih yang berjumlah 53 buah. Pura ini tergolong Pura Luhuring Ambal-Ambal yang terdiri dari tujuh Mandala yang melambangkan Sapta Loka. Dalam Raja Purana Besakih dikatakan bahwa Pura Penataran Agung Besakih adalah tempat Pesamuaning Batara Kabeh. Penelitian ini difokuskan pada bagian Mandala 1, 5, 6 dan 7. Mandala 1 terdiri dari enam unsur diantaranya Candi Bentar, Bale Pegat, Bale Kulkul, Bale Pelegongan, Bale Pegambuhan, dan Bale Ongkara. Untuk Mandala 5, 6, dan 7 termasuk di dalam satu areal bangunan Pura Penataran Agung. Adapun Mandala 5 memiliki empat unsur di antaranya Meru Tumpang 3, dua Bale Pepelik, Meru Tumpang 11. Mandala 6 memiliki dua unsur yaitu Pelinggih Purusa dan Pradana atau Pelinggih Rwa Bhineda. Mandala 7 hanya ada bidang kosong, dimana hanya ada rumpun bambu. Pada penelitian ini menggunakan metode SDLC (Software Development Life Cycle) Waterfall.

\section{METODE}

\section{A. Metode Penelitian}

Metode penelitian yang digunakan adalah Software Development Life Cycle (SDLC) waterfall. Metode SDLC model waterfall merupakan suatu proses pengembangan perangkat lunak yang berurutan, dimana setiap tahap harus diselesaikan terlebih dahulu sebelum memasuki tahap berikutnya yang dilihat sebagai aliran air yang terus mengalir melewati tahap-tahap yang ada yaitu tahapan Analisis, Desain, Implementasi dan Tes [18].

1) Tahap analisis

Tahap ini merupakan pengumpulan informasi dan kebutuhan secara lengkap kemudian dianalisis dan didefinisikan kebutuhan yang harus dipenuhi oleh aplikasi yang akan dibangun. Pada tahap ini dilakukan sebuah analisis masalah, analisis kebutuhan yang meliputi kebutuhan fungsional dan non fungsional.

2) Tahap Desain

Tahapan ini merupakan tahapan membuat rancangan dari aplikasi. Pada pengembangan Virtual Reality untuk Digitalisasi Pura Penataran Agung bagian Mandala 1, 5, 6 dan 7 di Pura Besakih ini, telah di rancang model fungsional perangkat lunak, bataan perancangan perangkat lunak, perancangan skenario aplikasi, dan perancangan antarmuka perangkat lunak.

3) Tahap Implementasi

Tahapan ini merupakan tahapan implementai aplikasi yang di implementasikan ke masyarakat umum, Dinas Kebudayaan Kabupaten Karangasem dan Manajemen Operasional Kawasan Pura Besakih.

4) Tahap Testing

Tahapan ini merupakan tahapan untuk mengetahui kekurangan maupun kelebihan dari aplikasi yang dikembangkan, sehingga aplikai masih bisa di perbaiki untuk mengurangi kesalahan-kesalahan yang terjadi sebelum aplikai di rilis ke masyarakat luas (pengguna). Pada tahap testing akan dilakukan 6 jenis pengujian yaitu Uji Whitebox, Uji Blackbox, Uji Usability, Uji Performance Efficiency, Uji Data Integrity, dan Uji Respon Pengguna.

Setelah melakukan análisis, terdapat beberapa fungsi penting yang akan digunakan untuk membuat aplikasi VR Pura Penataran Agung Besakih bagian Mandala 1, 5, 6 dan 7 diantaranya sebagai berikut :

1) Aplikasi dapat menjelajah di sekitar areal Mandala 1, 5, 6 dan 7 di Pura Penataran Agung Besakih

2) Aplikasi dapat menampilkan objek Pura dan lingkungan Pura dalam 3 Dimensi. 
3) Aplikasi dapat menampilkan informasi dalam bentuk audio dan teks tentang objek-objek di Pura Penataran Agung Besakih

Berdasarkan analisis kebutuhan, software yang dibutuhkan untuk mengembangkan aplikasi virtual reality yaitu :

1) Blender digunakan untuk membuat objek 3 Dimensi dari Pura Penataran Agung Besakih

2) Photoshop digunakan untuk mengedit tekstur objek dari Pura Penataran Agung Besakih

3) Unity 3D dengan SteamVR Library yang digunakan untuk membuat aplikasi Virtual Reality.

4) Audacity yang digunakan untuk mengedit suara untuk penjelasan informasi objek Pura.

Perangkat keras yang digunakan untuk pengembangan dan implementasi dari aplikasi yaitu :

1) PC yang digunakan untuk mengembangkan dan mengimplementasi aplikasi

2) HTC VIVE

\section{B. Konsep Digitalisasi Bangunan Pura}

Konsep awal dari penelitian Virtual Reality untuk Digitalisasi Pura Penataran Agung bagian Mandala 1, 5, 6 dan 7 yaitu ada tiga tahapan yaitu sebagai berikut:

1. Tahap pertama mengambil gambar asli Pura dengan menggunakan kamera untuk mengambil gambar bangunan Pura dengan teknik pengambilan gambar yaitu dari depan, belakang, samping kanan, samping kiri, pojok kanan depan, pojok kiri depan, pojok kanan belakang, dan pojok kiri belakang serta perhitungan perspektif untuk mendapatkan pengukuran yang tepat.

2. Tahap kedua yaitu pengembangan objek 3D Pura dengan menggunakan Blender dan proses tekstur menggunakan tekstur bangunan asli Pura agar nantinya terlihat asli.

3. Tahap ketiga adalah pengembangan aplikasi dengan menggunakan Unity dan SteamVR serta alat VR yang digunakan adalah HTC Vive. Berikut adalah konsep Digitalisasi Pura Penataran Agung bagian Mandala 1, 5, 6 dan 7 di Pura Besakih pada Gambar 1.

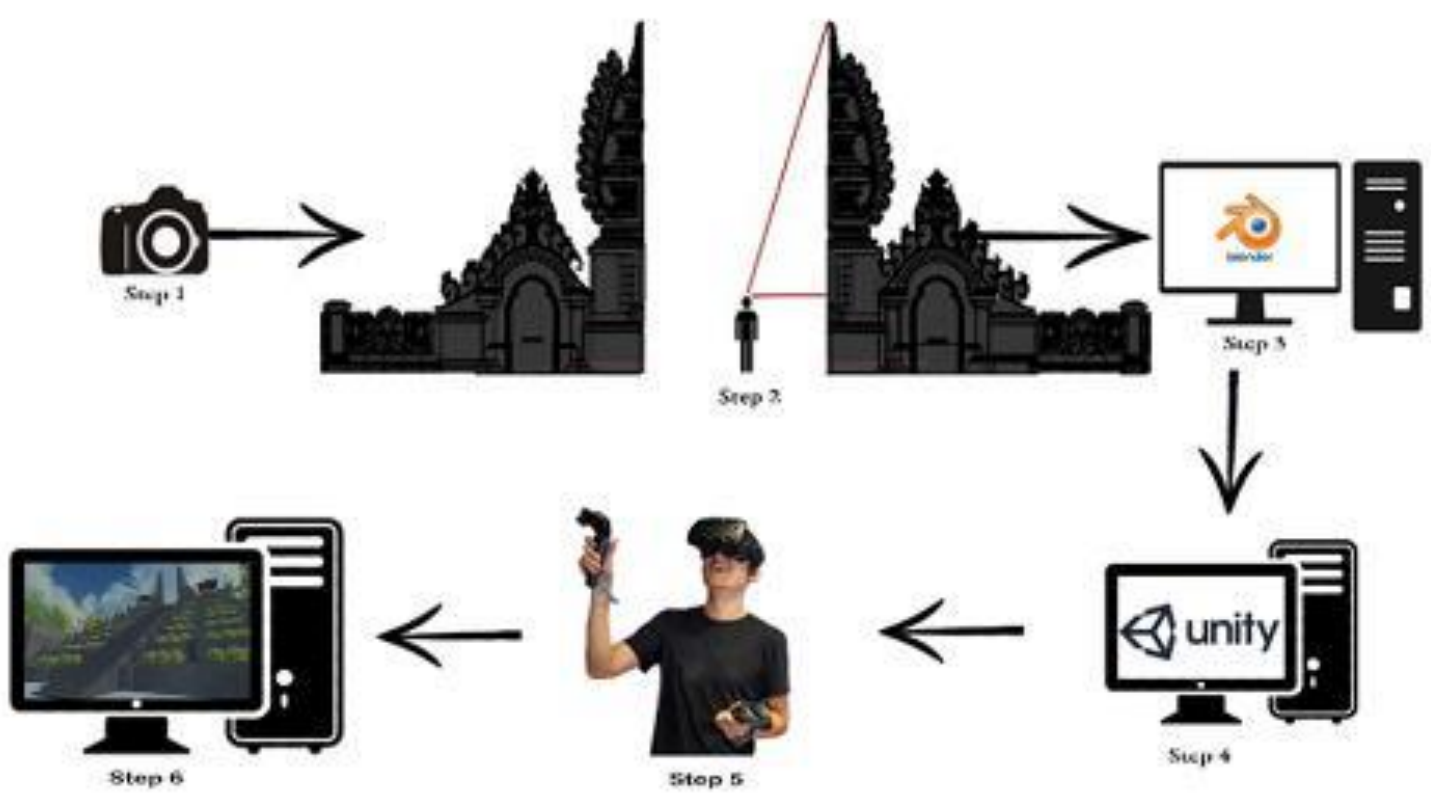

Gambar 1. Langkah-langkah pengembangan aplikasi Virtual Reality

\section{HASIL}

\section{A. Hasil Penelitian}

\section{a. Rancangan Use Case Diagram}

Perancangan dari Use Case Diagram digunakan untuk menjelaskan secara visual konteks dari interaksi antara actor dan sistem. Setiap use case menyatakan spesifikasi perilaku (fungsionalitas) dari sistem yang sedang dijelaskan memang dibutuhkan oleh actor untuk memenuhi tujuannya [19]. Berikut rancangan Use Case Diagram dari aplikasi VR Pura Penataran Agung Besakih dijelaskan pada Gambar 1. 


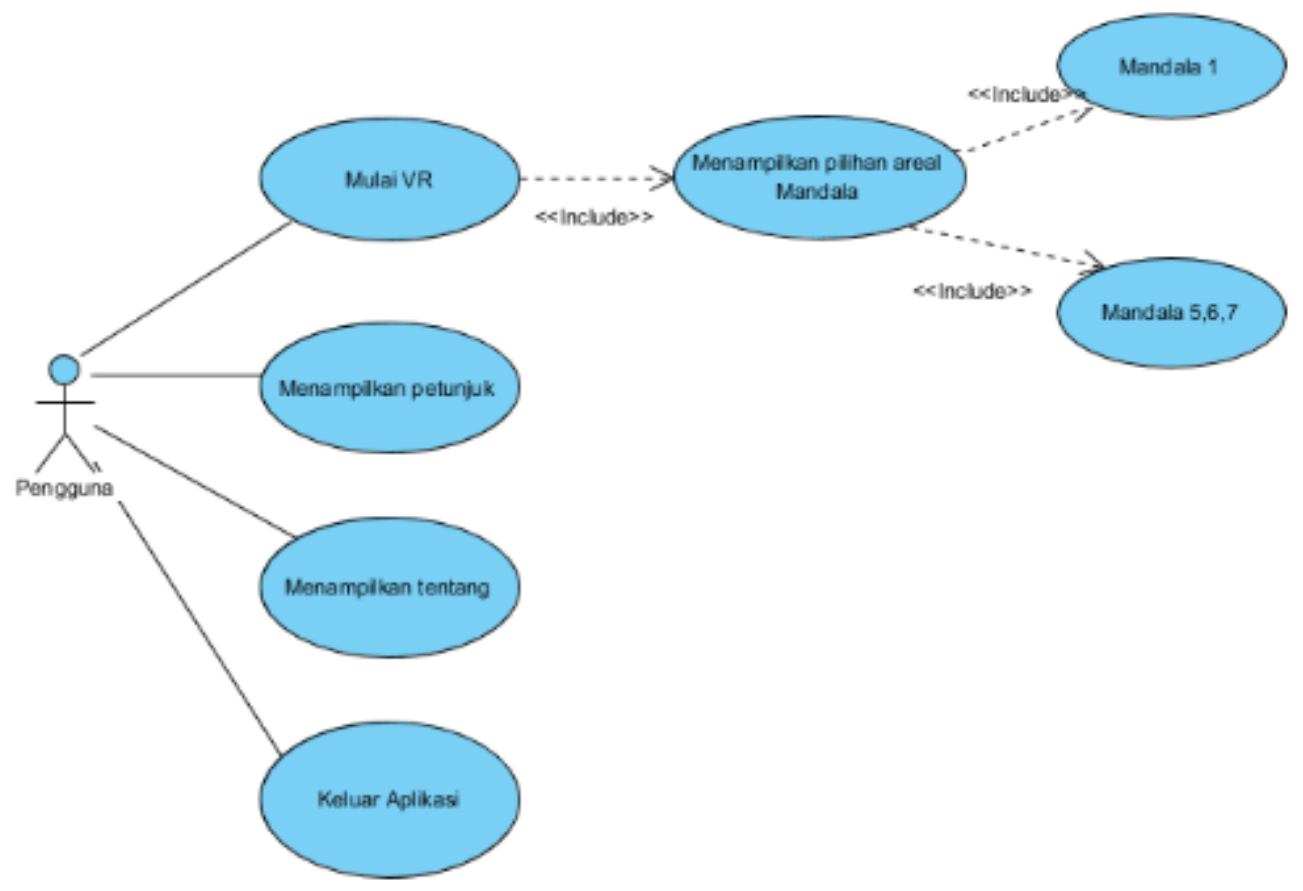

Gambar 2. Use Case Diagram Aplikasi VR Pura Penataran Agung Besakih Mandala 1, 5, 6 dan 7

Pada Gambar 2 menunjukkan hubungan pengguna dengan aplikasi yang dihubungkan dengan garis directed association, dimana garis directed association berhubungan langsung dengan use case saat menjalankan aplikasi.

Berikut implementasi dari use case diagram yang sesuai dengan masing-masing actor, dimana tampilan aplikasi menu utama ada pada Gambar 3 dan 4.

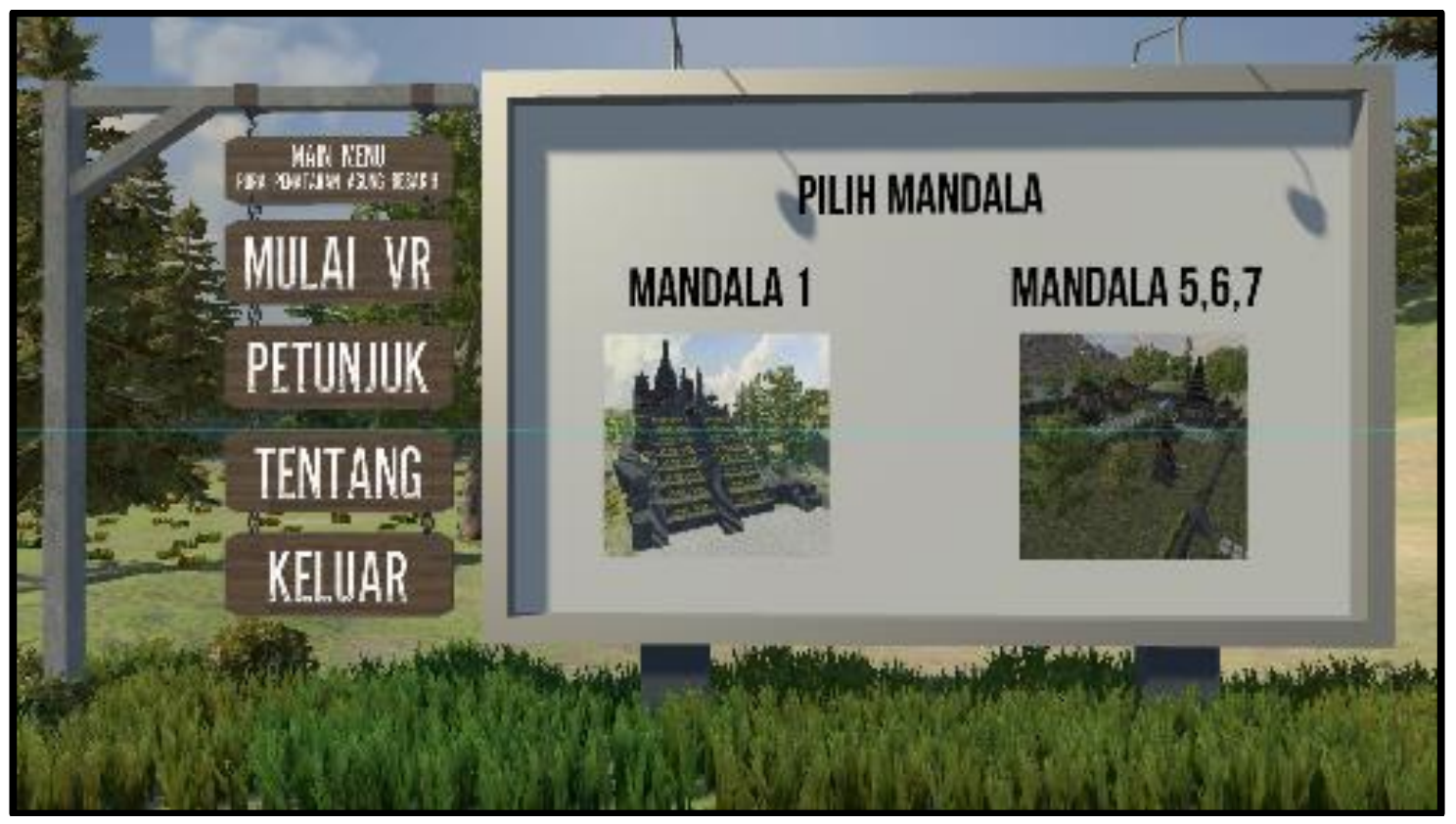

Gambar 3. Implementasi Tampilan Menu Utama

Tahapan implementasi aplikasi Gambar 3 untuk pengguna dapat mengakses menu yang ada pada aplikasi sesuai dengan use case diagram yang telah dirancang. 


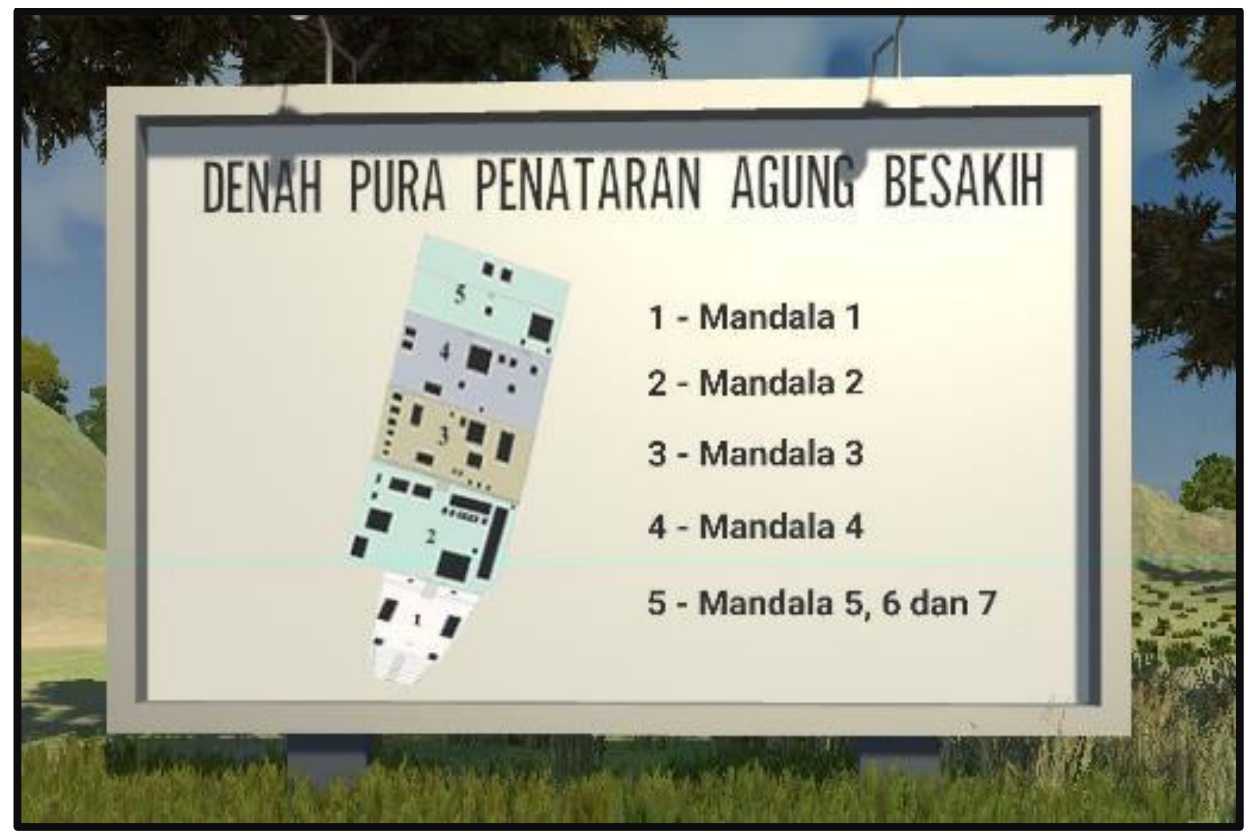

Gambar 4. Tampilan Denah dari Pura Penataran Agung Besakih

Pada Gambar 4 menampilkan denah dari Pura Penataran Agung Besakih.

\section{b. Implementasi Objek 3 Dimensi}

Pada tahap kedua dalam pengembangan Virtual Reality adalah membuat objek 3 Dimensi dan animasinya. Software yang digunakan yaitu Blender versi 2.79b. Dalam pengembangan objek 3 Dimensi dan animasi menggunakan beberapa tahap yaitu :

1) Modeling, proses membuat mesh 3D (karakter dan objek 3D lainnya) menggunakan beberapa Mesh Tools seperti plane, cube, circle, uv sphere, icosphere, cylinder, cond, grid dan torus. Teknik ini digunakan pada saat meng-extrude dan memodifikasi mirror.

2) Material dan Teksturing, proses yang digunakan untuk menyimulasikan warna atau properti pada mesh 3D. Proses ini didasarkan pada interpretasi foto asli untuk material asli atau material yang lain yang dapat menghasilkan warna dan tekstur yang serupa dengan aslinya.

3) Setelah objek dan areal Pura sudah selesai, selanjutnya dipindahkan ke Unity3D.

Berikut implementasi tampilan di setiap areal Pura yaitu mulai dari Mandala 1, Mandala 5, Mandala 6 dan Mandala 7 beserta hasil bangunan asli dengan model 3D.

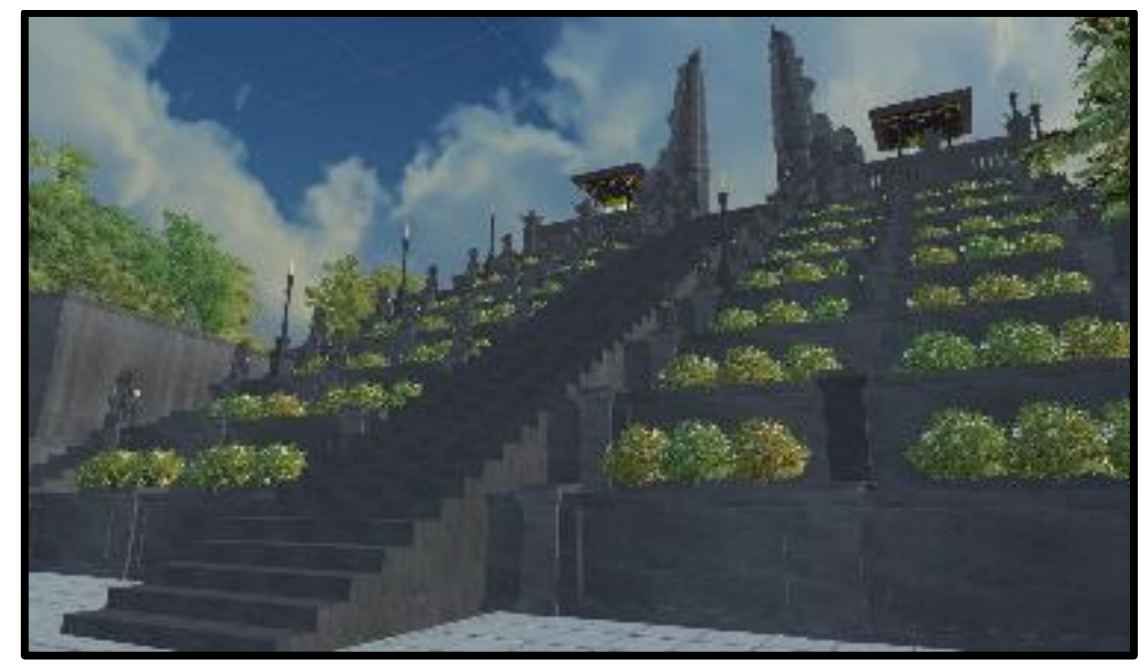

Gambar 5. Tampilan Area Mandala 1 
Pada tampilan Gambar 5, areal ini terletak di paling depan dari Pura Penataran Agung Besakih dengan 51 tangga dan 36 patung.

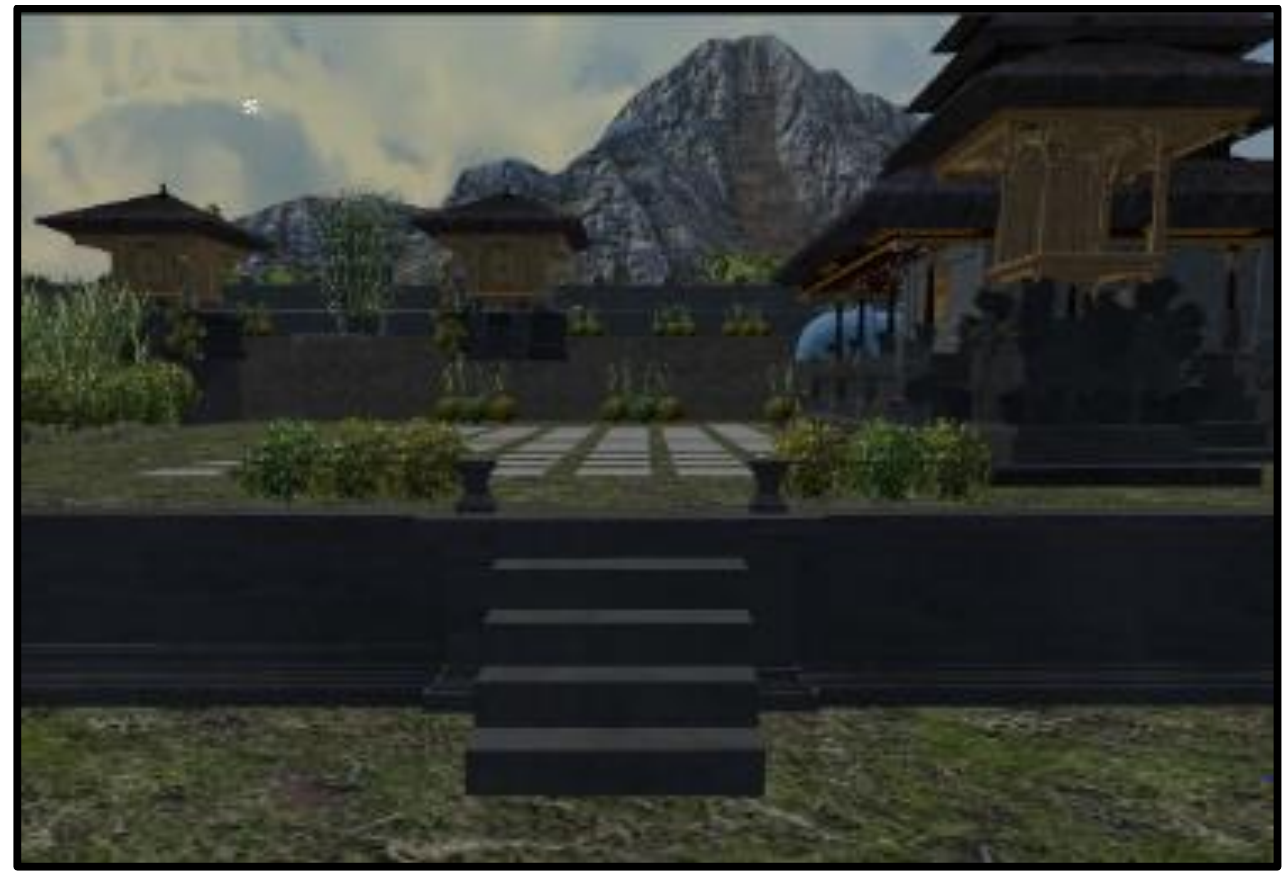

Gambar 6. Tampilan Area Mandala 5

Pada tampilan Gambar 6, areal ini terletak di belakan, tepatnya sebelum Mandala 6 dengan 4 objek bangunan.

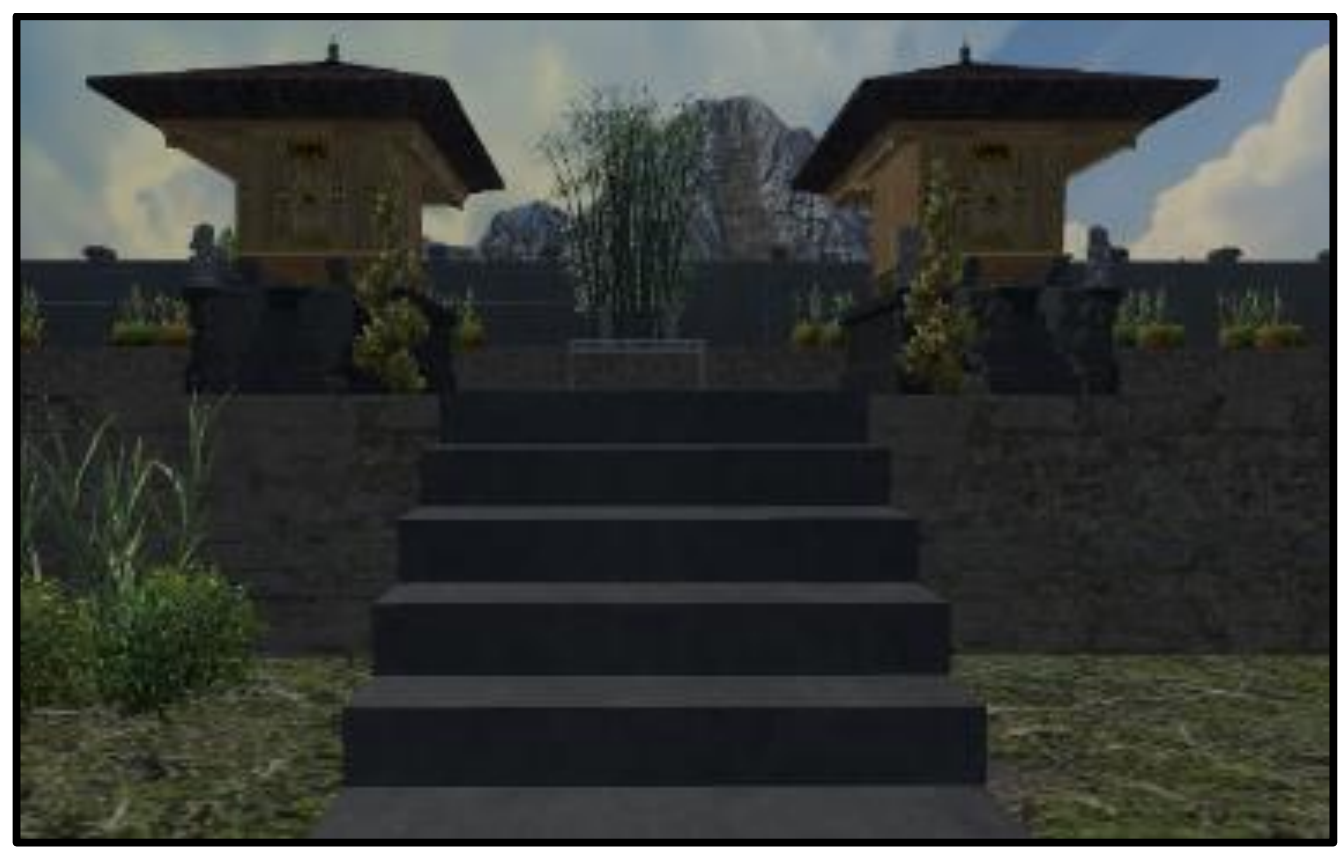

Gambar 7. Tampilan Area Mandala 6

Pada tampilan Gambar 7, areal ini terletak di belakang setelah Mandala 5 dengan 2 gedong pelinggihnya. 


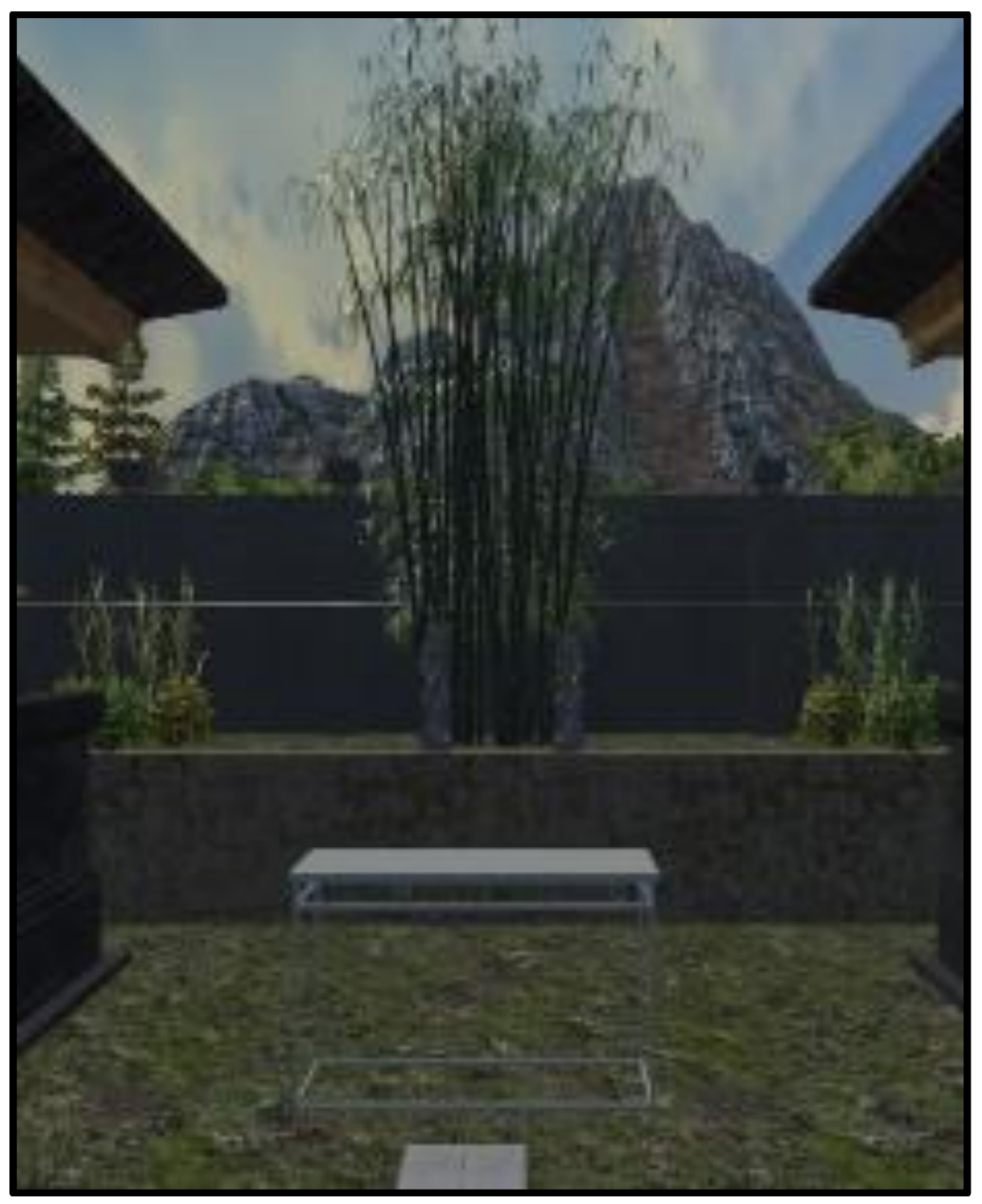

Gambar 8. Tampilan Area Mandala 7

Pada tampilan Gambar 8, areal ini terletak di paling belakang dari Pura Penataran Agung, dimana hanya ada bidang kosong dan rumpun bambu dan hanya berupa sebidang petak tanah.

\section{c. Perbandingan Objek 3 Dimensi dengan Objek Asli}

Berikut perbandingan dari objek asli dari Pura dengan objek hasil pemodelan 3 Dimensi pada Gambar 7, Gambar 8, dan Gambar 9.
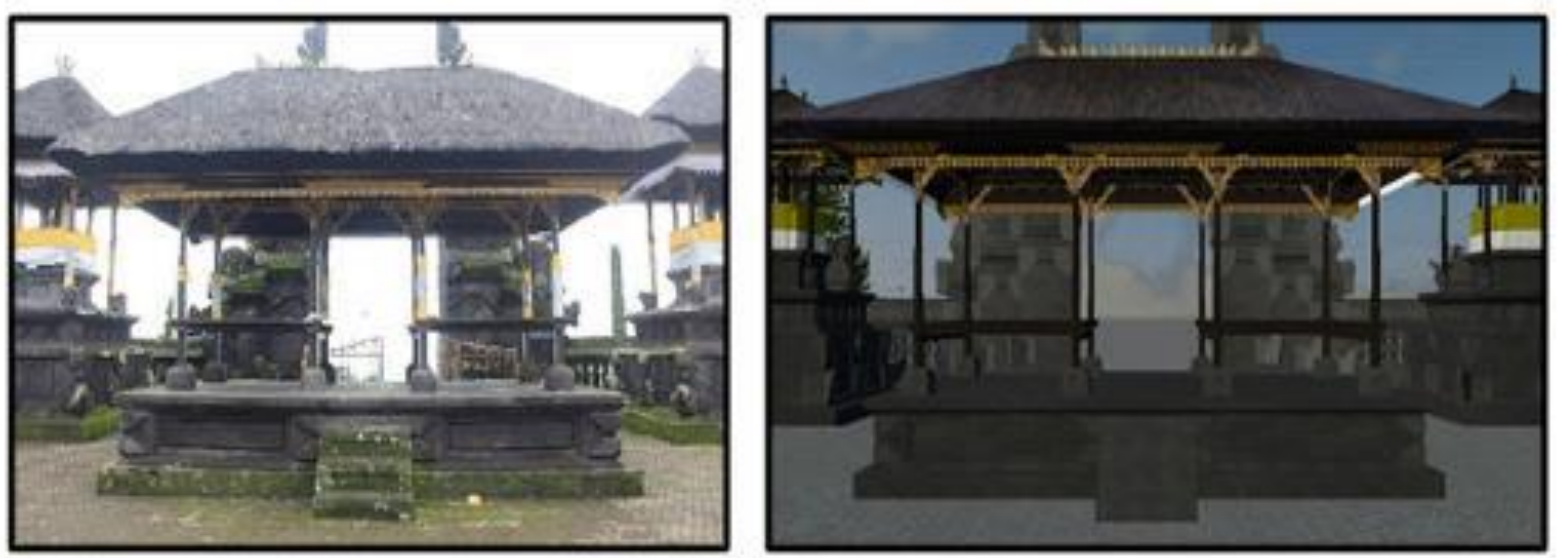

Gambar 9. Bale Pegat

Pada tampilan Gambar 9 merupakan bangunan yang bernama Bale Pegat yang terletak di areal Mandala 1 dari Pura Penataran Agung Besakih. Bale Pegat merupakan tempat untuk menyucikan diri sebelum memasuki areal lebih dalam di Pura. 

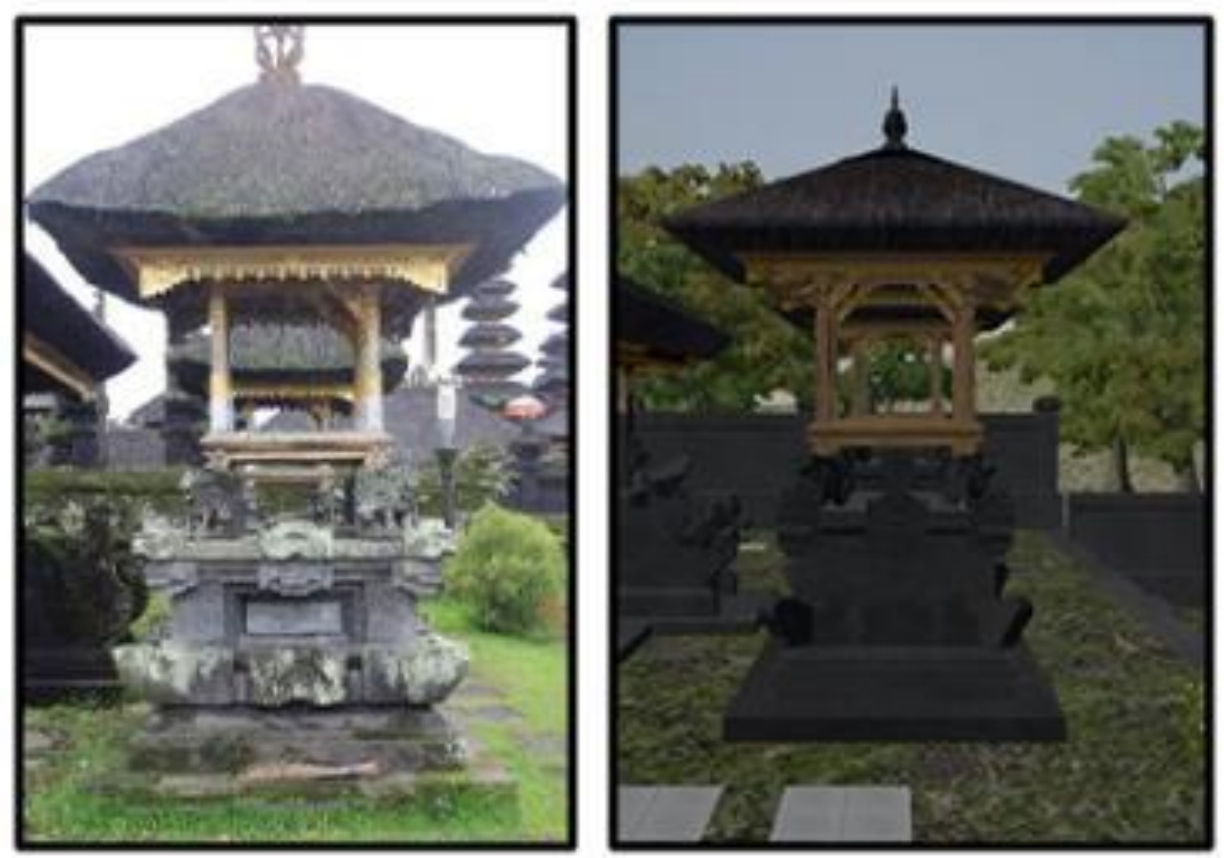

Gambar 10. Bale Pepelik

Pada tampilan Gambar 10 merupakan bangunan yang bernama Bale Pepelik yang terletak di areal Mandala 5 dari Pura Penataran Agung Besakih. Bale Pepelik merupakan tempat untuk menghaturkan banten atau sesaji ke hadapan Ida Sang Hyang Widhi Wasa.
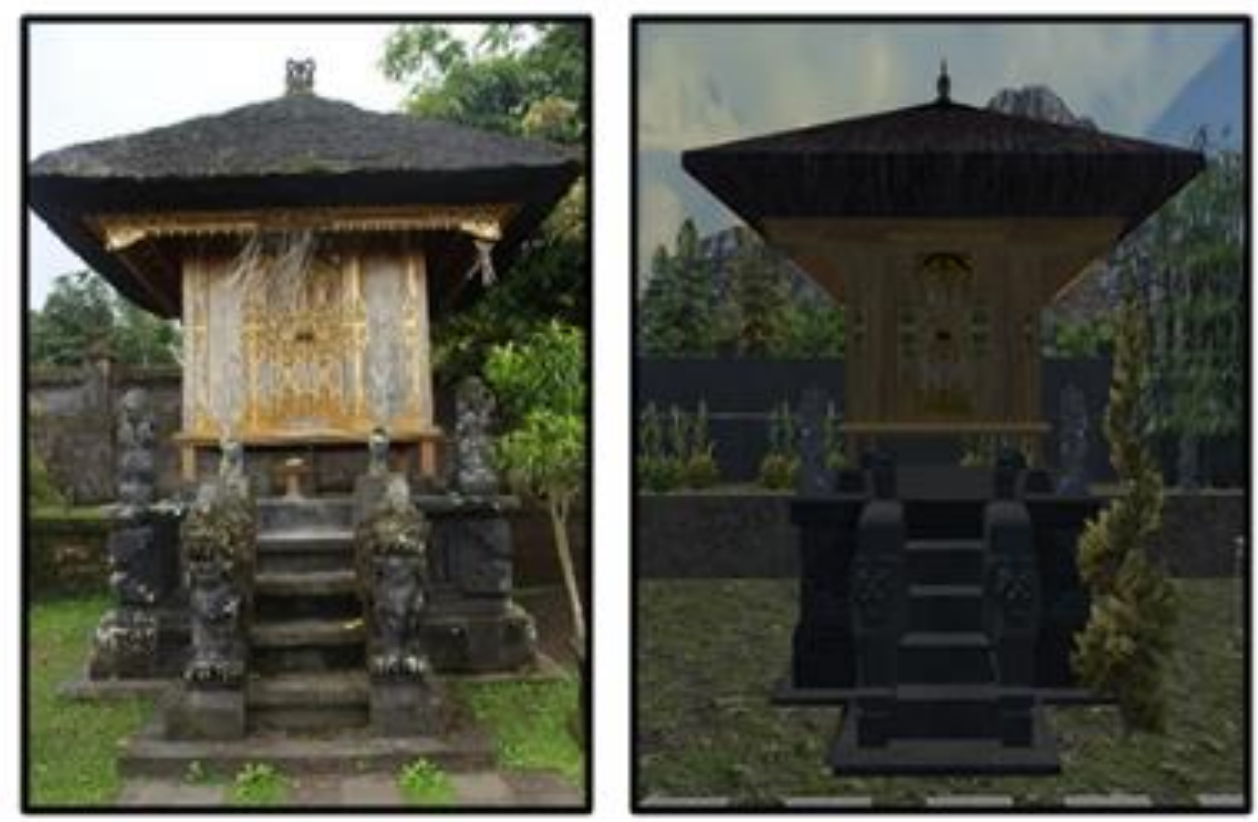

Gambar 11. Gedong Pelinggih Ida Ratu Bukit Kiwa

Pada tampilan Gambar 11 merupakan bangunan yang bernama Gedong Pelinggih Ida Ratu Bukit Kiwa yang terletak di areal Mandala 6 dari Pura Penataran Agung Besakih. Gedong Pelinggih Ida Ratu Bukit Kiwa merupakan Linggih Ratu Purusa, dimana distanakan Hyang Putranjaya, putra Hyang Pasupati.

\section{d. Implementasi Aplikasi Virtual Reality}

Pengembangan aplikasi Virtual Reality menggunakan aplikasi Unity3D. Sebelum bekerja dengan Unity3D, SteamVR harus sudah dipasang pada perangkat PC untuk dapat menggunakan fitur Virtual Reality. SteamVR dapat diunduh di website Unity, https://assetstore.unity.com/.

1) Selanjutnya objek 3D di-impor ke Unity3D, adapun file tersebut berformat (.fbx) beserta tekstur dari semua objek 3D. 
2) Selanjutnya membuat sejumlah scene di dalam Unity 3D, dimana scene tersebut disimpan di folder Asset. Banyaknya scene di dalam folder Asset tergantung dari banyaknya Pura. Sebagai contoh, areal Pura dibagi menjadi 2 bagian, sehingga scene dibuat menjadi 2 bagian. Setiap scene pada Unity3D terdapat CameraRig, Directional Light, SteamVR Laser Pointer dan SteamVR Teleporter.

3) Selanjutnya menset area Teleport yang akan digunakan untuk menjalankan teleporter di Unity3D, collider harus diset pada objek untuk dijadikan sebagai target oleh teleporter. Sebagai contoh, di dalam aplikasi VR yang sudah dikembangkan, halaman dari Pura dijadikan sebagai target teleport sehingga pengguna dapat berjalan di sekitar areal Pura dengan mengarahkan controller ke halaman Pura.

4) Langkah terakhir yaitu proses build aplikasi Virtual Reality. Pengaturan build aplikasi dapat diset di menu pengaturan build file. Di dalam pengaturan ini, pengguna dapat memilih scene yang akan dibuild dan dapat menambahkan ikon aplikasi. Setelah itu, aplikasi Virtual Reality dapat dibangun dan dijalankan pada perangkat PC. Hasil akhir dapat berupa format .exe.

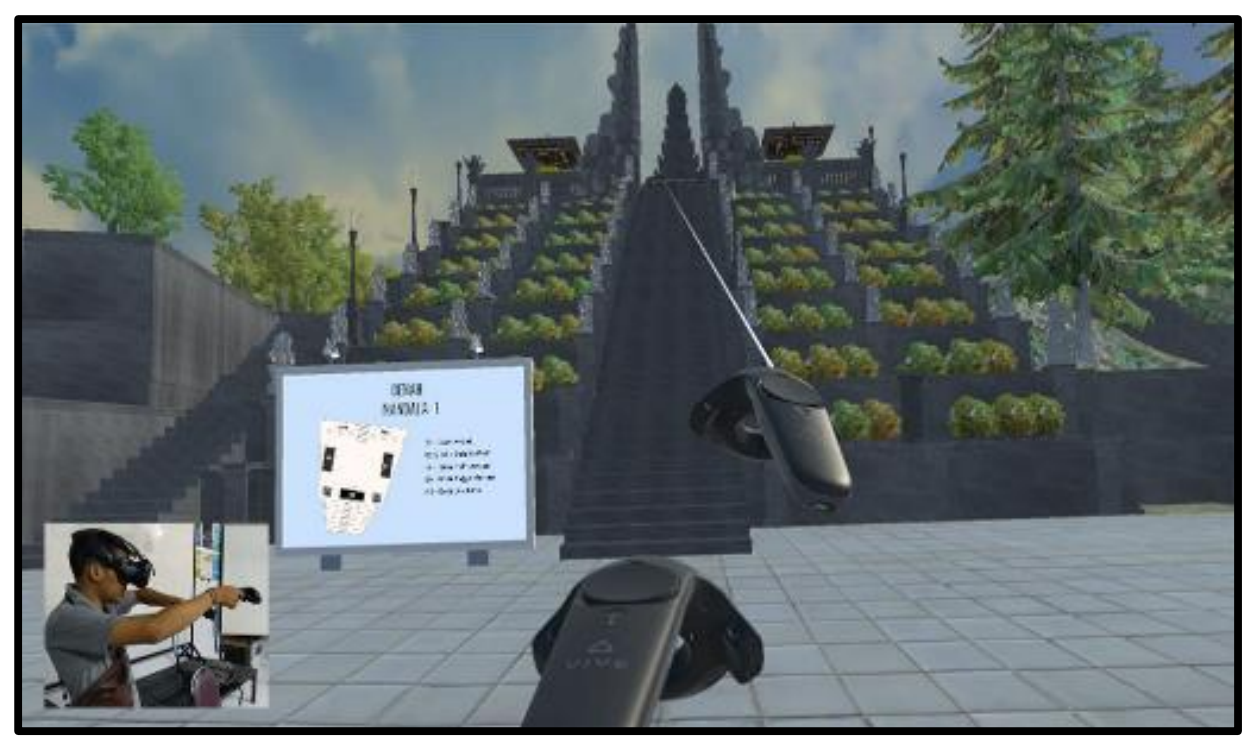

Gambar 12. Implementasi Aplikasi VR Masuk ke Mandala 1

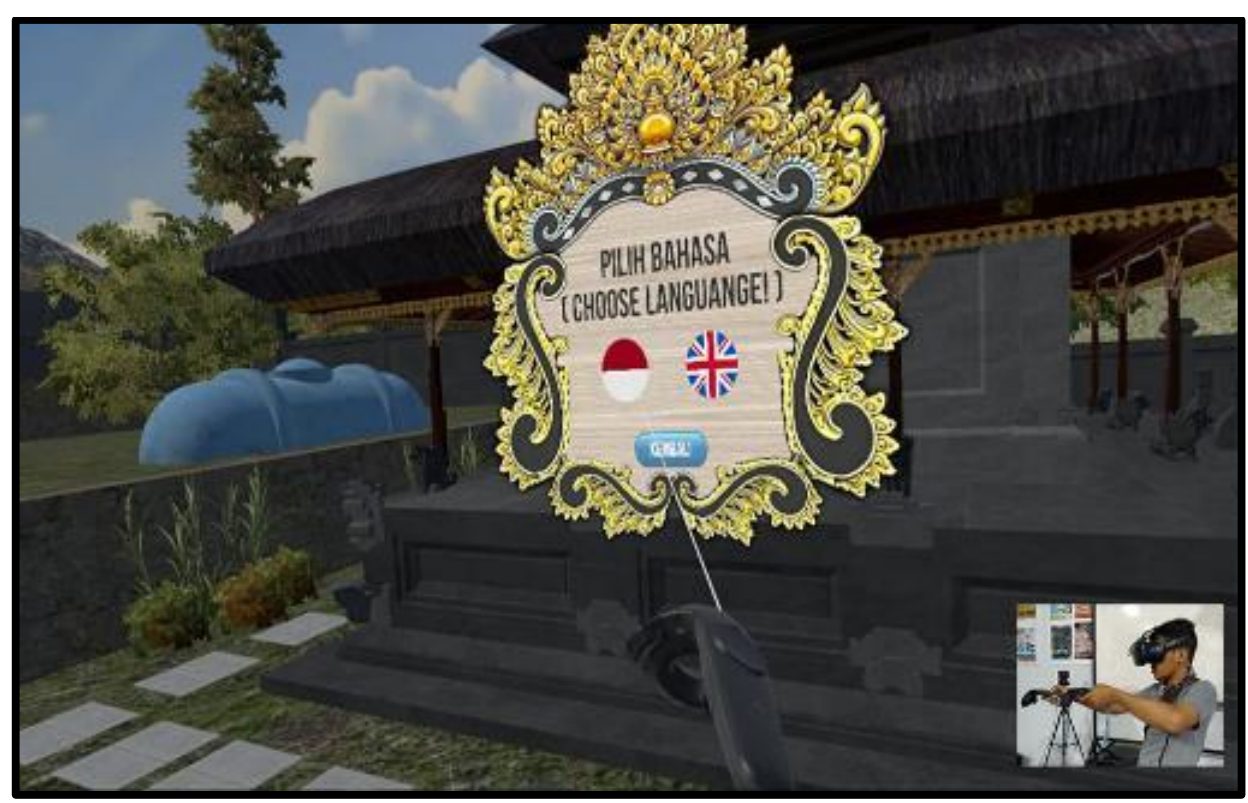

Gambar 13. Implementasi Aplikasi VR Memilih Informasi 


\section{PEMBAHASAN}

Aplikasi ini dapat menjelajah di sekitar areal Pura di tempat menggunakan Virtual Reality yang memungkinkan pengguna merasakan visualisasi warisan budaya Bali, yang dalam hal ini adalah Pura Penataran Agung Besakih. Pengguna dapat berjalan di Pura dan dapat melihat objek 3D dari Pura Penataran Agung Besakih serta terdapat narasi dalam bentuk teks dan suara dari setiap objek 3D Pura dengan diiringi musik latar.

Ada beberapa tes yang sudah peneliti lakukan dimana berdasarkan hasil uji persyaratan fungsional (blackbox testing), aplikasi Virtual Reality ini sudah berjalan dengan baik seperti yang diharapkan. Semua fitur yang telah dikembangkan telah berjalan dengan baik. Peneliti juga menguji aplikasi ini dengan ahli isi untuk menguji keakuratan bentuk dan tata letak setiap objek 3D yang dibuat di aplikasi Virtual Reality beserta kelengkapan dan kesesuaian informasi setiap objek di Pura Penataran Agung Besakih pada bagian Mandala 1, 5, 6 dan 7. Keakuratan objek dan lanskap yang diujikan mendapatkan persentase sebesar 89\%. Dimana dari hasil uji tersebut, ada beberapa informasi dari objek perlu dipoles. Selain itu, peneliti melakukan uji untuk memvalidasi terhadap visual-design, interface, audio, time-behavior, resource utilization dan capacity dari aplikasi yang dilakukan dengan 5 orang responden didapatkan persentase sebesar 86\%. Dan juga melakukan uji untuk melihat tingkat kemudahan dan kenyamanan pengguna dalam menggunakan aplikasi ini yang dilakukan dengan 5 responden didapatkan persentase sebesar $80 \%$.

Untuk mendapatkan tanggapan dari masyarakat, aplikasi ini ditempatkan di Pura Besakih tepatnya di Sasana Budaya dan Dinas Kebudayaan Kabupaten Karangasem. Kuesioner yang digunakan untuk menguji pengalaman pengguna menggunakan aplikasi ini adalah angket User Experience Questionnaire (UEQ). UEQ digunakan untuk mengukur pengalaman pengguna menggunakan produk interaktif. Skala kuesioner mencakup keduanya yaitu aspek kegunaan klasik (efisiensi, perspektif, ketergantungan) dan aspek pengalaman pengguna (orisinalitas, stimulasi) dengan pemberian angket dengan ada 26 item pertanyaan yang akan diberikan kepada pengguna.

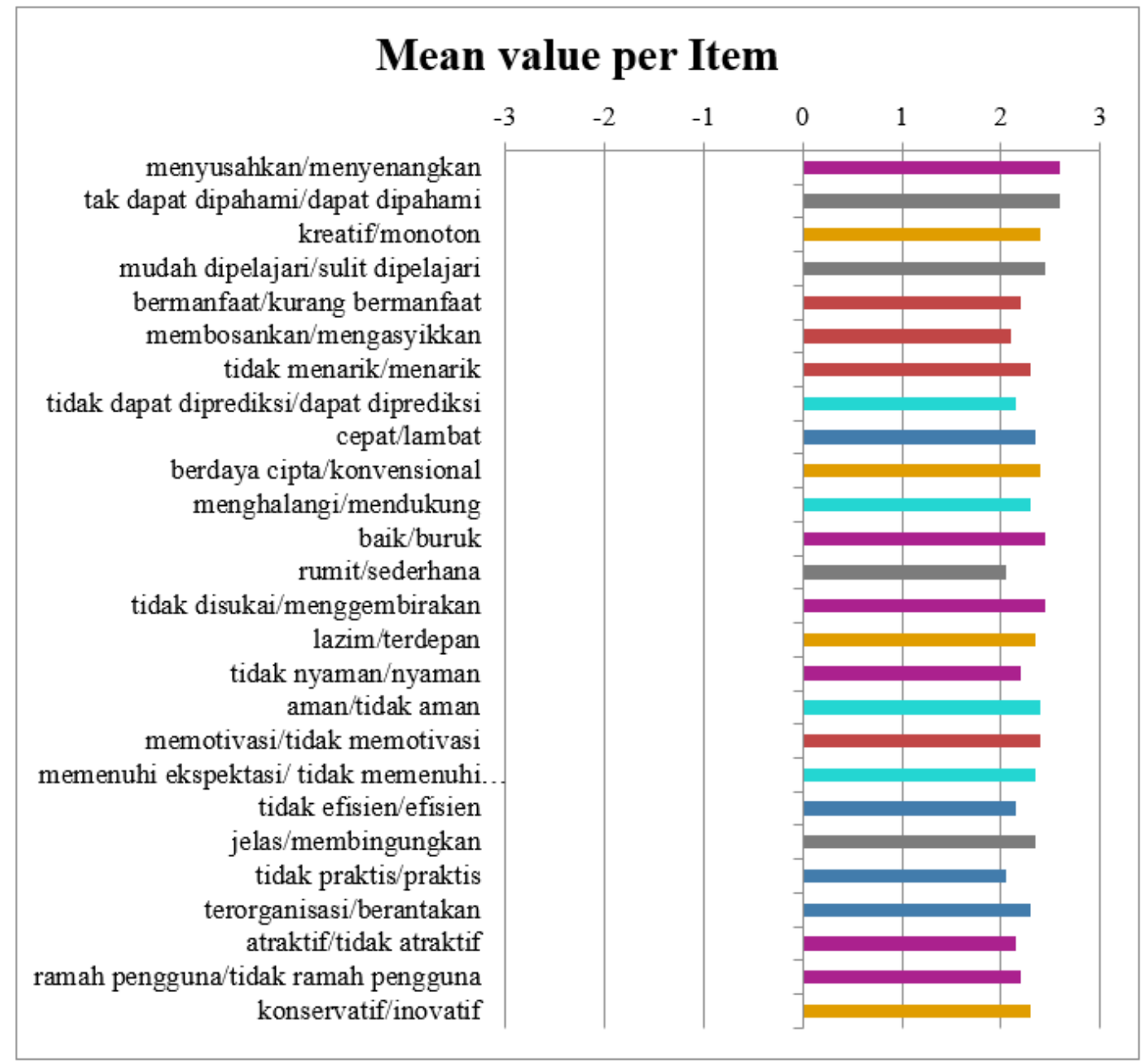

Gambar 14. Nilai rata-rata impresi kelompok 
Pada Gambar 14 menunjukkan grafik nilai rata-rata setiap item pertanyaan dalam posisi negatif, nol atau positif.

Tabel 1. Nilai Rata-Rata Impresi Kelompok

\begin{tabular}{lcc}
\hline \multicolumn{3}{c}{ UEQ Scales (Mean and Variance) } \\
\hline Daya tarik & 2.342 & 0.02 \\
Kejelasan & Tิ 2.363 & 0.08 \\
Efisiensi & Tิ 2.213 & 0.07 \\
Ketepatan & Tิ 2.300 & 0.08 \\
Stimulasi & 2.250 & 0.09 \\
Kebaruan & T 2.363 & 0.06 \\
\hline
\end{tabular}

Pada Tabel 1 menampilkan nilai rata-rata dari keseluruhan item pertanyaan dilihat dari kelompoknya.

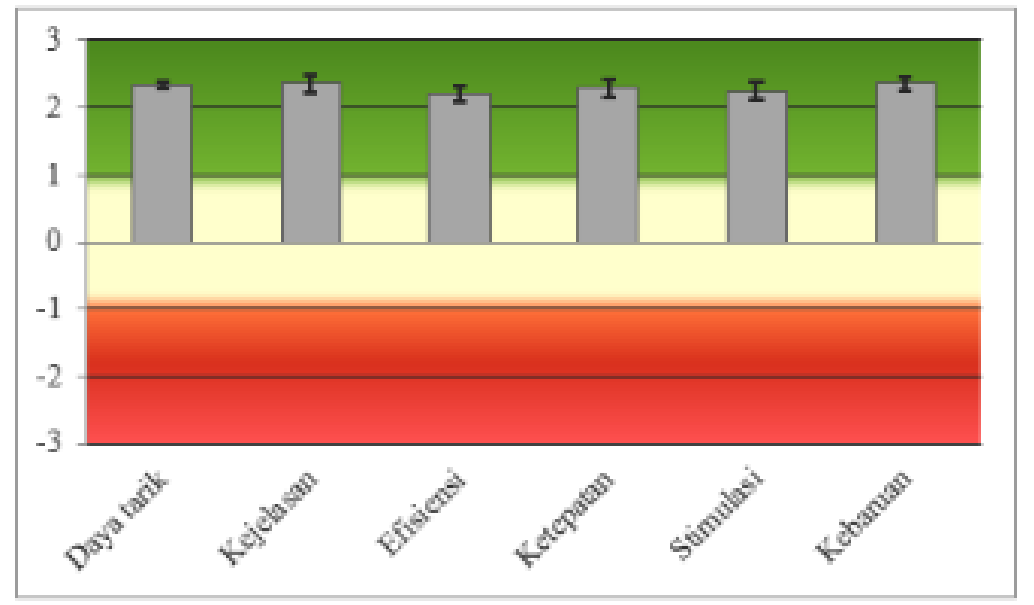

Gambar. 15 Grafik nilai rata-rata impresi kelompok

Pada Gambar 15 menunjukkan grafik nilai rata-rata setiap pertanyaan sesuai kelompoknya. Nilai rata-rata respon antara -0.8 dan 0.8 merupakan nilai evaluasi positif dan nilai-nilai kurang dari -0.8 merupakan evaluasi negatif.

Sehingga berdasarkan 20 responden dengan berbagai usia dan latar belakang, peneliti menunjukkan bahwa aplikasi Virtual Reality untuk Digitalisasi Pura Penataran Agung bagian Mandala 1, 5, 6 dan 7 memiliki kesan positif berturut-turut dalam kelompok Daya Tarik, Kejelasan, Efisiensi, Akurasi, Stimulasi dan Kebaruan. Aplikasi Virtual Reality ini menarik masyarakat dari segala usia untuk menggunakan dan mencoba aplikasi ini. Mereka memberikan respon sangat positif terhadap aplikasi yang telah dikembangkan.

\section{SIMPULAN DAN SARAN}

Pengembangan aplikasi Virtual Reality untuk Digitalisasi Pura Penataran Agung bagian Mandala 1, 5, 6 dan 7 di Pura Besakih membantu untuk mendokumentasikan warisan budaya di Bali, dimana aplikasi ini bertujuan untuk melestarikan warisan budaya Bali dan mencegah hilangnya informasi penting hal-hal negatif seperti bencana alam terjadi di masa depan. Selain itu, aplikasi ini dapat digunakan sebagai alat untuk memperkenalkan budaya Bali kepada masyarakat yang tertarik untuk tahu lebih banyak. Aplikasi VR ini dapat membantu pengguna untuk mencari informasi tentang Pura Penataran Agung sebagai bagian dari Pura Besakih dan sebagai warisan budaya. Aplikasi ini dapat digunakan sebagai dokumentasi untuk warisan budaya untuk Dinas Kebudayaan Kabupaten Karangasem berupa Virtual Gallery dan untuk dokumentasi di Manajemen Operasional Kawasan Pura Besakih selain itu dapat juga menarik minat wisatawan untuk mencoba aplikasi, selain itu aplikasi ini membantu memperkenalkan Pura di Bali secara global. 


\section{Daftar Pustaka}

Anggoro, P. (2018). Kajian Interaksi Pengguna untuk Navigasi Aplikasi Prambanan VR Berbasis Virtual Reality. Journal Teknologi Informasi dan Ilmu Komputer, 239.

Babad Bali - Pura Penataran Agung. (2018, November 27). Retrieved from babadbali.com: http://www.babadbali.com/pura/plan/besakih/penataran-agung.htm.

Bekele, M. K., Town, C., Pierdicca, R., Frontoni, E., \& Malinverni, E. V. (2018). "A Survey of Augmented , Virtual , and Mixed Reality. ACM J. Comput. Cult. Herit., 36.

Chavan, S. R. (2016). Augmented Reality vs. Virtual Reality: Differences and Similarities. Int. J. Adv. Res. Comput. Eng. Technol., 2278-1323.

Crisnapati, P. N., Darmawiguna, I. G., Kesiman, M. W., \& Wijaya, B. K. (2019). 3D Digitalization of Besakih Arhitectural Heritage: Documentation and Preservation. Journal of Physics, Conference Series .

Darmawiguna, I G M, et al. (2014). Augmented Reality for the Documentation of Cultural Heritage Building in Bali Indonesia. Kultur un Informatic, Reality Virtualilty.

M. Nguyen, H. T., \& H. Le. (2015). Exploration of the 3D World on the Internet Using Commodity Virtual Reality Devices,. Multimodal Technol. Interact.

Pedersen, A. (2002). Managing Tourism at World Heritage Sites: a Practical Manual for World Heritage Site Managers, 1st. ed. Paris: UNESCO World Heritage Center.

Pranata, M. A., Santyadiputra, G. S., \& Sindu, I. G. (2017). Rancangan Game Balinese Fruit Shooter Berbasis Virtual Reality Sebagai Media Pembelajaran. JANAPATI.

Sutriyanti, K. (2015). Pelinggih Padmatiga Penataran Agung Besakih. Vidya Samhita, 76-96. 